\title{
FAKTOR YANG MEMENGARUHI KESIAPAN IBU PREMENOPAUSE MENGHADAPI MASA MENOPAUSE DI KOMPLEK ASRAMA KHATULISTIWA KOTA PONTIANAK TAHUN 2021
}

\author{
Putri Rizky Parlina Nababan ${ }^{1}$ \\ ${ }^{1}$ Institut Kesehatan Helvetia, Medan. \\ Email: ${ }^{1}$ bidanputrinababan25@gmail.com
}

\begin{abstract}
Abstrak
Menopause adalah suatu bagian akhir dari proses biologis siklus menstruasi yang terjadi dikarenakan oleh penurunan produksi hormon estrogen yang dihasilkan oleh ovarium. Tahun 2016 di Indonesia baru mencapai 14 juta perempuan menopause atau $7,4 \%$ dari total populasi yang ada dan pada tahun 2020 jumlahnya diperkirakan mencapai $11,54 \%$. Tujuan penelitian untuk mengetahui dan menganalisa faktor yang memengaruhi kesiapan ibu premenopause menghadapi masa menopause di Komplek Asrama Khatulistiwa Kota Pontianak Tahun 2021. Jenis penelitian ini menggunakan Mix Methods dengan strategi metode Eksplanatoris Sekuensial. Penelitian dilakukan di Komplek Asrama Khatulistiwa Kota Pontianak. Populasi berjumlah 48 orang, sampel dengan teknik total sampling sebanyak 48 responden, sedangkan informan kualitatif 3orang perwakilan ibu premenopause. Hasil uji chi-square diperoleh pada variabel tingkat pendidikan $\mathrm{p}=0,009$, status pekerjaan $p=0,006$, pengetahuan $p=0,002$, sikap $p=0,005$, tingkat stress $p=0,007$, dukungan keluarga $\mathrm{p}=0,004$, aktivitas fisik $\mathrm{p}=0,006$ yang menunjukkan adanya faktor yang memengaruhi kesiapan ibu premenopause menghadapi masa menopause. Variabel yang sangat berpengaruh adalah sikap ibu premenopause dengan nilai $\operatorname{Exp(B)} 22,625$. Kesimpulan dalam penelitian ini adalah ada pengaruh tingkat pendidikan, status pekerjaan, pengetahuan, sikap, tingkat stress, dukungan keluarga, aktivitas fisik terhadap kesiapan ibu premenopause menghadapi masa menopause di Komplek Asrama Khatulistiwa Kota Pontianak Tahun 2021. Disarankan kepada tempat penelitian agar penelitian ini dapat dijadikan sebagai bahan informasi dan masukan saat dilakukannya penyuluhan atau kegiatan kesehatan lainnya, khususnya bagi ibupremenopause agar dapat mempersiapkan diri dengan baik dalam menghadapi masa menopause kelak.
\end{abstract}

Kata Kunci: Tingkat Pendidikan, Status Pekerjaan, Pengetahuan,Sikap, Tingkat Stress, Tingkat Stress, Aktivitas Fisik, Kesiapan Menghadapi Menopause

\begin{abstract}
Menopause is an end of the biological process of the menstrual cycle that occurs due to decreased production of the hormone estrogen produced by the ovaries. In 2016, Indonesia reaches 14 million menopausal women or $7.4 \%$ of the total population and in 2020 the number is estimated to reach 11,54\%. The purpose of the study was to determine and analyze the factors affecting in pramenopausal mother's readliness time of menopause at Khatulistiwa Dormitory Complex in Pontianak City 2021. This type of research uses Mix Methods with a sequential explanatory method strategy. The research was conducted at Khatulistiwa's Dormitory Complex in Pontianak City. The population is 48 people, the sample with total sampling technique is 48 respondents, while the qualitative informants are 3 representative of premenopausal mothers. The results of the chi-square test were obtained on the eduction level variable $p=0,009$, employment status $p=0,006$, knowledge $p=0,002$, attitude $p=0,005$, stress level $p=0,007$, family support $p=0,004$, physical activity $p=0,006$ which indicates the presence of the factors affecting in pramenopausal mother's readliness time of menopause. The most effect variable is the attitude of premenopausal mothers with the value of Exp
\end{abstract}




\section{MIRACLE JOURNAL}

(B) 22,625. The conclusion in this study is that there is an effect of education level, employment status, knowledge, attitude, stress level, family support, physical activity on the pramenopausal mother's readliness time of menopause at Khatulistiwa's Dormitory Complex in Pontianak City 2021. It is suggested to the research site that this research can be used as information and input material when doing counseling or other health activities, especially for premenopausal mothers in order to prepare in readliness time of menopause later.

Keywords: Level of Education, Knowledge, Attitude, Stress Level, Family Support, Physical Activity, Readliness Time of Menopause

\section{Pendahuluan}

Menjadi tua merupakan suatu proses yang merupakan bagian dari kehidupan seseorang. Konsep menjadi tua telah ada sejak dalam kandungan dan terus berlangsung sepanjang kehidupan. Usia lanjut mengandung pengertian adanya perubahan yang agresif pada organisme atau seseorang yang telah mengalami kematangan. Perubahan pada manusia ini bersifat irreversible atau tidak dapat kembali (1).

Menurut World Health Organization (WHO) pada tahun 2030, jumlah perempuan di seluruh dunia yang memasuki masa menopause diperkirakan mencapai 1,2 miliar orang. Di Indonesia, pada tahun 2025 diperkirakan akan ada 60 juta perempuan menopause. Pada tahun 2016 di Indonesia baru mencapai 14 juta perempuan menopause atau 7,4\% dari total populasi yang ada dan pada tahun 2020 jumlahnya diperkirakan mencapai 11,54\%. Angka harapan hidup perempuan terus meningkat dalam 10 tahun terakhir. Pada 2011, angka harapan hidup perempuan tercatat sebesar 72,02 tahun, angkanya lalu menyentuh 73 tahun pada tahun 2017 dan pada tahun 2020 menjadi 73,46 tahun. Sementara perkiraan umur ratarata usia menopause di Indonesia adalah 48 tahun (2).

Peningkatan usia harapan hidup menyebabkan jumlah perempuan yang mengalami menopause semakin banyak sehingga menopause juga memiliki dampak negatif lainnya selain keluhan - keluhan awal yang dirasakan yakni terjadinya peningkatan kasus penyakit degeneratif atau penyakit tidak menular. Menurut Badan Pusat Statistik tahun 2019, angka kesakitan usia lansia yang terjadi di indonesia adalah sebesar 26,2\% kejadian kesakitan dengan berbagai penyakit seperti risiko osteoporosis, risiko penyakit jantung, risiko kanker payudara, risiko kanker leher rahim, dan risiko kanker rahim (2).

Berdasarkan data dari Badan Pusat Statistik Provinsi Kalimantan Barat pada tahun 2020 jumlah penduduk sebesar 5.414.390 jiwa dengan jumlah penduduk di Kota Pontianak pada tahun 2020 yaitu sebesar 658.685 jiwa dengan jumlah penduduk wanita sebesar 328.956 jiwa dan dengan jumlah ibu premenopause sebesar 46.243 jiwa (3).

Menopause merupakan gejala dalam kehidupan perempuan yang ditandai dengan berhentinya siklus menstruasi. Menopause merupakan fase alami dalam kehidupan setiap wanita yang ditandai dengan berakhirnya masa subur. Menopause sebagaimana kehamilan merupakan suatu peristiwa yang dianggap sangat berarti bagi seorang wanita (1).

Menstruasi pada remaja perempuan menunjukkan diproduksinya hormon estrogen. Sementara itu, menopause merupakan suatu proses yang terjadi dikarenakan ovarium tidak lagi menghasilkan atau tidak lagi memproduksi hormon estrogen. Defenisi menopause, dalam Poltekkes Gorontalo (2013), adalah penghentian fungsi mastural yang berlangsung selama masa klimakterium pada perempuan. Penghentian fungsi mastural ini meliputi perubahan emosional pada perempuan. Menopause juga disebut sebagai sebuah proses surutnya haid yang tidak berlangsung secara drastis tetapi berlangsung secara perlahanlahan (1). 
Sebelum memasuki menopause, seorang perempuan akan memasuki masa pramenopause atau yang disebut juga dengan masa klimakterium. Klimakterium merupakan masa peralihan antara masa reproduksi dan masa senium. Klimakterium hampir sama dengan menopause yakni merupakan masa berakhirnya masa reproduksi. Biasanya terjadi pada awal senium dan terjadi pada wanita dengan kisaran usia 40-50 tahun. Masa klimakterium ditandai dengan berbagai macam keluhan pada wanita tersebut. Ciri-cirinya antara lain sering mengeluarkan banyak keringat, sering kedinginan, sakit kepala, gejolak panas, dan bising telinga. Sementara itu, yang berkaitan dengan psikologis adalah ditandai dengan perubahan mood, sensitif, mudah tersinggung, depresi, kelelahan, lemah dan semangat berkurang (1).

Berhentinya menstruasi secara menetap membawa konsekuensi kesehatan baik fisik maupun psikis yang dapat menjadi fatal bila tidak ditangani dengan serius. Fungsi reproduksi yang menurun menimbulkan dampak yaitu ketidaknyamanan dalam menjalani kehidupan. Bagi sebagian wanita, menopause menimbulkan rasa cemas dan risau. Hal ini akan menjadi tekanan dan semakin memberatkan apabila wanita tersebut selalu berpikiran negatif.

Begitu juga kesiapan dalam menghadapi masa menopause, ada beberapa faktor yang memengaruhi seperti pendidikan dan tingkat pendidikan yang mempengaruhi pengetahuan tentang masa menopause, sosial ekonomi yang mempengaruhi faktor fisik dan kesehatan, budaya dan lingkungan yang sangat berpengaruh besar terhadap cara wanita menanggapi proses berhentinya haid, riwayat kesehatan yang dapat mempengaruhi kondisi psikologis serta umur yang berpengaruh terhadap bertambahnya pengalaman sehingga akan lebih siap dalam menghadapi menopause (4).

Melihat fenomena tersebut, maka peneliti tertarik melakukan penelitian tentang Faktor Yang Memengaruhi Kesiapan Ibu Premenopause Menghadapi Masa Menopause Di Komplek Asrama Khatulistiwa Kota Pontianak Tahun 2021, dengan tujuan untuk mengetahui dan menganalisa faktor yang memengaruhi kesiapan ibu premenopause menghadapi masa menopause.

\section{Metode Penelitian}

Penelitian ini dilakukan tahun 2021 dengan jenis penelitian menggunakan Mix Methods dengan strategi metode Eksplanatoris Sekuensial. Pendekatan yang digunakan dalam kuantitatif yaitu cross sectional dan kualitatif menggunakan grounded theory. Populasi berjumlah 48 orang, sampel dengan teknik total sampling sebanyak 48 responden ibu premenopause usia 40-50 tahun, sedangkan informan kualitatif 3 orang perwakilan ibu premenopause. Pendekatan kuantitatif dilakukan dengan memberikan kuesioner kepada responden dan pendekatan kualitatif dilakukan dengan wawancara mendalam menggunakan pedoman wawancara yang bertujuan menggali lebih dalam bagaimana faktor yang memengaruhi kesiapan ibu premenopause menghadapi masa menopause.

\section{Hasil Penelitian}

\section{Analisis Univariat}


Berdasarkan karakteristik responden pada umur, dapat dilihat bahwa dari 48 responden didapatkan 26 orang $(54,2 \%)$ berumur $40-45$ tahun dan 22 orang $(45,8 \%)$ berumur 46 - 50 tahun.

Berdasarkan tingkat pendidikan, dapat dilihat dari 48 responden, responden dengan tingkat pendidikan "Dasar" yaitu sebanyak 4 orang $(8,4 \%)$, responden dengan tingkat pendidikan "Menengah" yaitu sebanyak 22 orang $(45,8 \%)$ dan responden dengan tingkat pendidikan "Atas" yaitu sebanyak 22 orang $(45,8 \%)$.

Berdasarkan status pekerjaan, dapat dilihat dari 48 responden, responden dengan status pekerjaan "Bekerja" yaitu sebanyak 19 orang $(39,6 \%)$ dan responden dengan status pekerjaan "Tidak Bekerja" yaitu sebanyak 29 orang $(60,4 \%)$.

Berdasarkan pengetahuan, dapat dilihat dari 48 responden, responden dengan pengetahuan "Baik" yaitu sebanyak 24 orang $(50 \%)$, responden dengan pengetahuan "Cukup" yaitu sebanyak 21 orang $(43,8 \%)$, dan responden dengan pengetahuan "Kurang" yaitu sebanyak 3 orang $(6,2 \%)$.

Berdasarkan sikap, dapat dilihat dari 48 responden, responden dengan sikap "Positif" yaitu sebanyak 17 orang $(35,4 \%)$ dan responden dengan sikap "Negatif" yaitu sebanyak 31 orang $(64,6 \%)$.

Berdasarkan tingkat stress, dapat dilihat dari 48 responden, responden dengan tingkat stress "stress sedang" yaitu sebanyak 5 orang $(10,4 \%)$, responden dengan tingkat stress "stress ringan" yaitu sebanyak 24 orang $(50 \%)$ dan responden dengan tingkat stress "tidak stress" yaitu sebanyak 19 orang $(39,6 \%)$.

Berdasarkan dukungan keluarga, dapat dilihat dari 48 responden, responden dengan dukungan keluarga "Mendukung" yaitu sebanyak 33 orang $(68,8 \%)$ dan responden dengan dukungan keluarga "Tidak Mendukung" yaitu sebanyak 15 orang $(31,2 \%)$.

Berdasarkan aktivitas fisik, dapat dilihat dari 48 responden, responden dengan aktivitas fisik "Tinggi" yaitu sebanyak 6 orang (12,5\%), responden dengan aktivitas fisik "Sedang" yaitu sebanyak 34 orang $(70,8 \%)$ dan responden dengan aktivitas fisik rendah yaitu sebanyak 8 orang $(16,7 \%)$.

Berdasarkan kesiapan menghadapi masa menopause, dapat dilihat dari 48 responden, responden dengan kesiapan menghadapi menopause "Siap" yaitu sebanyak 20 orang $(41,7 \%)$ dan responden dengan kesiapan menghadapi menopause "Tidak Siap" yaitu sebanyak 28 orang $(58,3 \%)$.

Tabel 1. Distribusi Responden Berdasarkan Umur, Tingkat Pendidikan, Status Pekerjaan, Pengetahuan, Sikap, Tingkat Stress, Dukungan Keluarga, Aktivitas Fisik dan Kesiapan Menghadapi Masa Menopause

\begin{tabular}{lcc}
\hline \multicolumn{1}{c}{ Variabel } & Frekuensi (f) & Persentase (\%) \\
\hline Umur : & 26 & \\
40-45 tahun & 22 & 54,2 \\
46-50 tahun & & 45,8 \\
Tingkat Pendidikan : & 4 & 8,4 \\
$\quad$ Dasar & 22 & 45,8 \\
Menengah & 22 & 45,8 \\
$\quad$ Atas & & \\
Status Pekerjaan : & 19 & 39,6 \\
$\quad$ Bekerja & 29 & 60,4 \\
$\quad$ Tidak Bekerja & 24 & 50 \\
Pengetahuan : & 21 & 43,8 \\
$\quad$ Baik & 3 & 6,2 \\
Cukup & & \\
Kurang & &
\end{tabular}




\begin{tabular}{lcc}
\hline Sikap : & 17 & 35,4 \\
$\quad$ Positif & 31 & 64,6 \\
$\quad$ Negatif & & \\
Tingkat Stress : & 19 & 39,6 \\
$\quad$ Tidak Stress & 24 & 10,4 \\
$\quad$ Stress Ringan & 5 & 68,8 \\
$\quad$ Stress Sedang & & 31,2 \\
Dukungan Keluarga : & 33 & \\
$\quad$ Mendukung & 15 & 16,7 \\
$\quad$ Tidak Mendukung & 8 & 70,8 \\
Aktivitas Fisik : & 34 & 12,5 \\
$\quad$ Aktivitas Fisik Rendah & 6 & 41,7 \\
$\quad$ Aktivitas Fisik Sedang & & 58,3 \\
$\quad$ Aktivitas Fisik Tinggi & 20 & $\mathbf{1 0 0}$ \\
Kesiapan Menghadapi Menopause: & 28 & \\
$\quad$ Siap & $\mathbf{4 8}$ & \\
$\quad$ Tidak Siap & & \\
\hline Total & & \\
\hline
\end{tabular}

Analisis Bivariat

Pengaruh Tingkat Pendidikan Terhadap Kesiapan Ibu Premenopause Menghadapi Masa Menopause

Berdasarkan hasil penelitian menunjukkan bahwa dari 4 responden ibu premenopause dengan tingkat pendidikan dasar didapatkan $2(4,2 \%)$ yang telah siap menghadapi masa menopause, dari 22 responden ibu premenopause dengan tingkat pendidikan menengah didapatkan $14(29,2 \%)$ yang tidak siap menghadapi masa menopause, dan dari 22 responden ibu premenopause dengan tingkat pendidikan atas 18 $(37,5 \%)$ yang siap menghadapi masa menopause. Dari hasil uji statistik, chi-square diperoleh nilai kemaknaan $\mathrm{p}=0,009(<0,05)$, maka dapat di simpulkan bahwa ada pengaruh tingkat pendidikan terhadap kesiapan ibu premenopause menghadapi masa menopause.

\section{Pengaruh Status Pekerjaan Terhadap Kesiapan Ibu Premenopause Menghadapi Masa Menopause}

Berdasarkan hasil penelitian menunjukkan bahwa dari 29 responden ibu premenopause dengan status bekerja didapatkan $17(35,4 \%)$ yang tidak siap menghadapi masa menopause dan dari 19 responden ibu premenopause dengan status tidak bekerja didapatkan 16 (33,3\%) yang siap menghadapi masa menopause. Dari hasil uji Statistik, chisquare diperoleh nilai kemaknaan $\mathrm{p}=0,006(<0,05)$, maka dapat di simpulkan bahwa ada pengaruh status pekerjaan terhadap kesiapan ibu premenopause menghadapi masa menopause.

\section{Pengaruh Pengetahuan Terhadap Kesiapan Ibu Premenopause Menghadapi Masa Menopause}

Berdasarkan hasil penelitian menunjukkan bahwa dari 24 responden ibu premenopause dengan pengetahuan baik didapatkan 20 (41,7\%) yang siap menghadapi masa menopause, dari 21 responden ibu premenopause dengan pengetahuan cukup didapatkan 14 (29,2\%) yang tidak siap menghadapi masa menopause dan dari 3 responden ibu premenopause dengan pengetahuan kurang didapatkan $2(4,2 \%)$ yang tidak siap menghadapi masa menopause. Dari hasil uji statistik, chi-square diperoleh nilai kemaknaan 


\section{MIRACLE JOURNAL}

$p=0,002(<0,05)$, maka dapat di simpulkan bahwa ada pengaruh pengetahuan terhadap kesiapan ibu premenopause menghadapi masa menopause.

\section{Pengaruh Sikap Terhadap Kesiapan Ibu Premenopause Menghadapi Masa Menopause}

Berdasarkan hasil penelitian menunjukkan bahwa dari 31 responden ibu premenopause dengan sikap positif didapatkan 23 (47,9\%) yang siap menghadapi masa menopause dan dari 17 responden ibu premenopause dengan sikap negatif didapatkan 12 (25\%) yang tidak siap menghadapi masa menopause. Dari hasil uji statistik, chi-square diperoleh nilai kemaknaan $\mathrm{p}=0,005(<0,05)$, maka dapat di simpulkan bahwa ada pengaruh sikap terhadap kesiapan ibu premenopause menghadapi masa menopause.

\section{Pengaruh Tingkat Stress Terhadap Kesiapan Ibu Premenopause Menghadapi Masa Menopause}

Berdasarkan hasil penelitian menunjukkan bahwa dari 19 responden ibu premenopause dengan tidak stress didapatkan $16(33,3 \%)$ yang siap menghadapi masa menopause, dari 24 responden ibu premenopause dengan stress ringan didapatkan 13 $(27,1 \%)$ yang tidak siap menghadapi masa menopause dan dari 5 responden ibu premenopause dengan stress sedang didapatkan $4(8,3 \%)$ yang tidak siap menghadapi masa menopause. Dari hasil uji statistik, chi-square diperoleh nilai kemaknaan $p=0,007(<0,05)$, maka dapat di simpulkan bahwa ada pengaruh tingkat stress terhadap kesiapan ibu premenopause menghadapi masa menopause.

\section{Pengaruh Dukungan Keluarga Terhadap Kesiapan Ibu Premenopause Menghadapi Masa Menopause}

Berdasarkan hasil penelitian menunjukkan bahwa dari 33 responden ibu premenopause dengan dukungan keluarga yang mendukung didapatkan 24 (50\%) yang siap menghadapi masa menopause dan dari 15 responden ibu premenopause dengan dukungan keluarga yang tidak mendukung didapatkan $11(22,9 \%)$ yang tidak siap menghadapi masa menopause. Dari hasil uji statistik, chi-square diperoleh nilai kemaknaan $p=0,004(<0,05)$, maka dapat di simpulkan bahwa ada pengaruh dukungan keluarga terhadap kesiapan ibu premenopause menghadapi masa menopause.

\section{Pengaruh Aktivitas Fisik Terhadap Kesiapan Ibu Premenopause Menghadapi Masa Menopause}

Berdasarkan hasil penelitian menunjukkan bahwa dari 8 responden ibu premenopause dengan aktivitas fisik rendah didapatkan $8(16,7 \%)$ yang siap menghadapi masa menopause, dari 34 responden ibu premenopause dengan aktivitas fisik sedang didapatkan $19(39,6 \%)$ yang siap menghadapi masa menopause dan dari 6 responden ibu premenopause dengan aktivitas fisik tinggi didapatkan $5(10,5 \%)$ yang tidak siap menghadapi masa menopause. Dari hasil uji statistik, chi-square diperoleh nilai kemaknaan $\mathrm{p}=0,006(<0,05)$, maka dapat di simpulkan bahwa ada pengaruh aktivitas fisik terhadap kesiapan ibu premenopause menghadapi masa menopause.

Tabel 2. Pengaruh Tingkat Pendidikan, Status Pekerjaan, Pengetahuan, Sikap, Tingkat Stress, Dukungan Keluarga dan Aktivitas Fisik Terhadap Kesiapan Ibu Premenopause Menghadapi Masa Menopause

$\begin{array}{lllll}\text { Variabel } & \text { Siap } & \text { Tidak Siap } & \text { Jumlah } & p \text {-value }\end{array}$




\section{MIRACLE JOURNAL}

\begin{tabular}{lccccccc}
\hline & $\mathbf{n}$ & $\mathbf{\%}$ & $\mathbf{n}$ & $\mathbf{\%}$ & $\mathbf{n}$ & $\mathbf{\%}$ & \\
\hline Tingkat Pendidikan : & & & & & & & \\
$\quad$ Dasar & 2 & 4,2 & 2 & 4,2 & 4 & 8,4 & \\
$\quad$ Menengah & 8 & 16,6 & 14 & 29,2 & 22 & 45,8 & 0,009 \\
$\quad$ Atas & 18 & 37,5 & 4 & 8,3 & 22 & 45,8 & \\
Status Pekerjaan : & & & & & & & \\
$\quad$ Bekerja & 12 & 25 & 17 & 35,4 & 29 & 60,4 & 0,006 \\
$\quad$ Tidak Bekerja & 16 & 33,3 & 3 & 6,3 & 19 & 39,6 & \\
Pengetahuan : & & & & & & & \\
$\quad$ Baik & 20 & 41,7 & 4 & 8,3 & 24 & 50 & \\
$\quad$ Cukup & 7 & 14,6 & 14 & 29,2 & 21 & 43,8 & 0,002 \\
$\quad$ Kurang & 1 & 2 & 2 & 4,2 & 3 & 6,2 & \\
Sikap : & & & & & & & \\
$\quad$ Positif & 23 & 47,9 & 8 & 16,7 & 31 & 64,6 & 0,005 \\
$\quad$ Negatif & 5 & 10,4 & 12 & 25 & 17 & 35,4 & \\
Tingkat Stress : & & & & & & & \\
$\quad$ Tidak Stress & 16 & 33,3 & 3 & 6,3 & 19 & 39,6 & \\
$\quad$ Stress Ringan & 11 & 22,9 & 13 & 27,1 & 24 & 50 & 0,007 \\
$\quad$ Stress Sedang & 1 & 2,1 & 4 & 8,3 & 5 & 10,4 & \\
Dukungan Keluarga : & & & & & & & \\
$\quad$ Mendukung & 24 & 50 & 9 & 18,8 & 33 & 68,8 & 0,004 \\
$\quad$ Tidak Mendukung & 4 & 8,3 & 11 & 22,9 & 15 & 31,2 & \\
Aktivitas Fisik : & & & & & & & \\
$\quad$ Aktivitas Fisik Rendah & 8 & 16,7 & 0 & 0 & 8 & 16,7 & \\
$\quad$ Aktivitas Fisik Sedang & 19 & 39,6 & 15 & 31,2 & 34 & 70,8 & 0,006 \\
$\quad$ Aktivitas Fisik Tinggi & 1 & 2 & 5 & 10,5 & 6 & 12,5 & \\
\hline Total & $\mathbf{2 8}$ & $\mathbf{5 8 , 3}$ & $\mathbf{2 0}$ & $\mathbf{4 1 , 7}$ & $\mathbf{4 8}$ & $\mathbf{1 0 0}$ & \\
\hline$\quad$
\end{tabular}

\section{Analisis Multivariat}

Berdasarkan hasil analisis multivariat menggunakan regresi logistik dengan menggunakan metode enter tersebut, ada 3 variabel indepenen (status pekerjaan, sikap, dan tingkat stress) yang dimasukkan kedalam analisis karena mempunyai nilai p-value $<0,05$ dan nilai Exp B $>1$ sehingga dapat dikatakan mempunyai pengaruh yang berarti terhadap kesiapan ibu premenopause menghadapi masa menopause. Pada penelitian ini variabel yang paling dominan berpengaruh terhadap kesiapan ibu premenopause menghadapi masa menopause adalah variabel sikap dengan nilai $\operatorname{Exp}(B) 22,625$.

Tabel 3. Hasil Analisis Multivariat Regresi Logistik antara Variabel Status Pekerjaan, Sikap dan Tingkat Stress Terhadap Kesiapan Ibu Premenopause Menghadapi Masa Menopause

\begin{tabular}{|c|c|c|c|c|c|}
\hline No & Variabel Penelitian & $D f$ & Sig. & $\operatorname{Exp}(B)$ & $\begin{array}{l}\text { 95\% C.I.for } \\
\operatorname{EXP(B)}\end{array}$ \\
\hline 1. & Status Pekerjaan & 1 & 0,011 & 15,166 & $1,850-124,354$ \\
\hline 2. & Sikap & 1 & 0,003 & 22,625 & $2,891-177,039$ \\
\hline 3. & Tingkat Stress & 1 & 0,007 & 0,102 & $0,019-0,533$ \\
\hline & Constant & 1 & $\mathbf{0 , 2 8 0}$ & 4,650 & \\
\hline
\end{tabular}

\section{Pembahasan}

Pengaruh Tingkat Pendidikan Terhadap Kesiapan Ibu Premenopause Menghadapi Masa Menopause 
Berdasarkan hasil tabulasi silang menunjukkan bahwa dari 4 responden ibu premenopause dengan tingkat pendidikan dasar didapatkan $2(4,2 \%)$ yang telah siap menghadapi masa menopause, dari 22 responden ibu premenopause dengan tingkat pendidikan menengah didapatkan $14(29,2 \%)$ yang tidak siap menghadapi masa menopause, dan dari 22 responden ibu premenopause dengan tingkat pendidikan atas 18 $(37,5 \%)$ yang siap menghadapi masa menopause. Dari hasil uji statistik, chi-square diperoleh nilai kemaknaan $\mathrm{p}=0,009(<0,05)$, maka dapat di simpulkan bahwa ada pengaruh tingkat pendidikan terhadap kesiapan ibu premenopause menghadapi masa menopause.

Penelitian ini sejalan dengan hasil penelitian Sukmawati yang menunjukkan bahwa dari 46 ibu premenopause dengan pendidikan tinggi yang siap menghadapi menopause sebanyak $25(100 \%)$ orang, sedangkan ibu yang pendidikan rendah yang tidak siap menghadapi menopause sebanyak $20(95,2 \%)$ orang. Berdasarkan uji chi-square diperoleh nilai $\mathrm{p}=0,000<\alpha(0,05)$ dapat dilihat ada pengaruh antara pendidikan terhadap kesiapan ibu premenopause dalam menghadapi menopause di Wilayah Kerja Puskesmas Kassi-kassi Makassar.

Secara kualitatif dapat diketahui bahwa informan 1 memiliki pendidikan terakhirnya dari sekolah dasar (SD), informan 2 memiliki pendidikan terakhir Sekolah Menengah Atas (SMA), dan informan 3 memiliki pendidikan terakhir Sarjana (S1). Dari ketiga informan tersebut, dapat didapatkan informasi bahwa tingkat pendidikan informan 1 adalah dasar (Sekolah dasar), informan 2 adalah menengah (SMA) dan informan 3 adalah Atas (S1 Pendidikan Guru).

Pendidikan adalah sebuah usaha sadar dan terencana untuk mewujudkan suasana belajar dan proses pembelajaran agar individu secara aktif mengembangkan potensi yang ada pada dirinya untuk memiliki kekuatan spiritual keagamaan, pengendalian diri, kepribadian, kecerdasan, akhlak mulia, serta keterampilan yang diperlukan dirinya dan masyarakat.

Menurut peneliti ibu premenopause dengan pendidikan atas sudah lebih siap dalam menghadapi masa menopause dibandingkan dengan ibu premenopause dengan tingkat pendidikan dasar dan menengah. Hal ini dikarenakan oleh kemampuan dan pemahanan tentang arti kesehatan serta pentingnya kesehatan yang lebih baik. Semakin tinggi tingkat pendidikan, maka akan semakin tinggi daya serapnya terhadap informasi sehingga informasi yang didapatkannya dapat dipahami dengan baik. Sebaliknya, semakin rendah tingkat pendidikan, maka pola pikirnya menjadi rendah sehingga daya serapnya terhadap informasi juga menjadi kurang. Walaupun demikian, tidak berarti bahwa ibu premenopause dengan tingkat pendidikan dasar dan menengah tidak siap menghadapi masa menopause.

\section{Pengaruh Status Pekerjaan Terhadap Kesiapan Ibu Premenopause Menghadapi Masa Menopause}

Berdasarkan hasil tabulasi silang menunjukkan bahwa dari 29 responden ibu premenopause dengan status bekerja didapatkan $17(35,4 \%)$ yang tidak siap menghadapi masa menopause dan dari 19 responden ibu premenopause dengan status tidak bekerja didapatkan $16(33,3 \%)$ yang siap menghadapi masa menopause. Dari hasil uji statistik, chisquare diperoleh nilai kemaknaan $\mathrm{p}=0,006(<0,05)$, maka dapat di simpulkan bahwa ada pengaruh status pekerjaan terhadap kesiapan ibu premenopause menghadapi masa menopause.

Hasil penelitian ini sejalan dengan penelitian Sri Wahyuni dkk, bahwa dari $224 \mathrm{ibu}$ premenopause dengan status bekerja yang siap menghadapi menopause sebanyak 65 $(50,7 \%)$ orang, sedangkan ibu dengan status tidak bekerja yang tidak siap menghadapi menopause sebanyak $26(28,2 \%)$ orang. Berdasarkan uji chi-square diperoleh nilai $\mathrm{p}=$ 
$0,011<\alpha(0,05)$ berarti ada pengaruh yang signifikan antara status pekerjaan terhadap kesiapan wanita dalam menghadapi menopause (7).

Pekerjaan adalah kebutuhan yang harus dilakukan terutama untuk menunjang kehidupan individu dan keluarganya. Bekerja pada umumnya merupakan pengaruh terhadap kehidupan kelurga dan memerlukan banyak aktivitas maka semakin tersita waktunya untuk datang ke unit pelayanan kesehatan. Pekerjaan ibu merupakan suatu kegiatan atau jenis pekerjaan yang dilakukan oleh seorang ibu untuk memenuhi kebutuhan sehari - hari. Ibu bekerja adalah ibu yang memiliki peran ganda yaitu sebagai ibu rumah tangga dan sebagai wanita pekerja (8).

Menurut peneliti tidak dapat disangkal bahwa kehadiran wanita di dalam dunia kerja sangat besar manfaatnya sebagai partner kaum pria yang tidak hanya sebagai ibu rumah tangga, dalam bekerja mereka juga dapat menyalurkan potensi dan bakat - bakat yang dimilikinya. Sebagian besar wanita yang bekerja akan lebih siap dan mampu menjalani masa menopause yang akan datang dengan baik dibandingkan dengan wanita yang tidak bekerja atau hanya sebagai ibu rumah tangga, dikarenakan pada wanita yang bekerja sudah terbiasa dengan aktivitas fisik dan masalah - masalah yang sering dihadapi dalam pekerjaan, sehingga ketakutan terhadap menopause lebih berkurang dan dianggap bukan masalah yang sulit untuk dihadapi.

\section{Pengaruh Pengetahuan Terhadap Kesiapan Ibu Premenopause Menghadapi Menopause di Asrama Khatulistiwa Kota Pontianak}

Berdasarkan hasil tabulasi silang menunjukkan bahwa dari 24 responden ibu premenopause dengan pengetahuan baik didapatkan $20(41,7 \%)$ yang siap menghadapi masa menopause, dari 21 responden ibu premenopause dengan pengetahuan cukup didapatkan 14 (29,2\%) yang tidak siap menghadapi masa menopause dan dari 3 responden ibu premenopause dengan pengetahuan kurang didapatkan $2(4,2 \%)$ yang tidak siap menghadapi masa menopause. Dari hasil uji statistik, chi-square diperoleh nilai kemaknaan $\mathrm{p}=0,002(<0,05)$, maka dapat di simpulkan bahwa ada pengaruh pengetahuan terhadap kesiapan ibu premenopause menghadapi masa menopause.

Hasil penelitian ini sejalan dengan penelitian Sasrawita, perhitungan analisis chisquare pada hubungan pengetahuan dengan kesiapan menopause diperoleh nilai $p$ value $=$ 0,011, maka dapat disimpulkan ada hubungan pengetahuan dengan kesiapan menghadapi menopause di Puskesmas Pekanbaru (9).

Pengetahuan adalah hasil dari tahu yang terjadi melalui proses sensoris khususnyamata dan telinga terhadap objek tertentu.Pengetahuan adalah segala sesuatu yang diketahui berkenaan dengan hal. Sedangkan menurut Notoatmodjo, pengetahuan merupakan hasil dari tahu dan ini terjadi setelah orang melakukan penginderaan terhadap suatu objek tertentu. Penginderaan yang terjadi melalui panca indera manusia, yaitu indera penglihatan, pendengaran, penciuman, rasa, dan raba. Pengetahuan atau kognitif merupakan domain yang sangat penting untuk terbentuknya tindakan seseorang (10).

Secara kualitatif diketahui bahwa pengetahuan informan 1 cukup dalam mengetahui tentang pengertian menopause, gejala menopause, merasakan sedikit gejala menopause dan mengerti dampak yang akan terjadi pada masa menopause menopause, pengetahuan informan 2 cukup mengetahui tentang pengertian masa menopause, merasakan sedikit gejala menopause dan mengerti apa dampak yang akan terjadi pada masa menopause, dan pengetahuan informan 3 juga baik mengetahui tentang pengertian masa menopause, belum merasakan gejala atau perubahan yang terjadi ketika memasuki masa menopause serta mengerti apa dampak yang akan terjadi pada masa menopause.

Menurut peneliti bahwa pengetahuan yang dimiliki oleh ibu pramenopause tentang masa menopause sudah baik dan sudah mengetahui seluk beluk tentang masa menopause 


\section{MIRACLE JOURNAL}

tersebut. Karena semakin baik pengetahuan ibu premenopause tentang menopause tersebut maka persiapan akan masa menopause juga sudah dipersiapkan dengan baik. Sebaliknya jika ibu pramenopause kurang memiliki pengetahuan yang baik tentang menopause maka akan timbul kurang mengertinya persiapan akan masa menopause tersebut.

\section{Pengaruh Sikap Terhadap Kesiapan Ibu Premenopause Menghadapi Menopause di Asrama Khatulistiwa Kota Pontianak}

Berdasarkan hasil tabulasi silang menunjukkan bahwa dari 31 responden ibu premenopause dengan sikap positif didapatkan 23 (47,9\%) yang siap menghadapi masa menopause dan dari 17 responden ibu premenopause dengan sikap negatif didapatkan 12 (25\%) yang tidak siap menghadapi masa menopause. Dari hasil uji statistik, chi-square diperoleh nilai kemaknaan $\mathrm{p}=0,005(<0,05)$, maka dapat di simpulkan bahwa ada pengaruh sikap terhadap kesiapan ibu premenopause menghadapi masa menopause.

Hasil penelitian ini sejalan dengan penelitian Novi dan Yuniliza, hasil penelitian menunjukkan bahwa dari 24 responden yang memiliki sikap negatif terdapat 18 responden $(75,0 \%)$ yang kurang siap dalam menghadapi menopause sedangkan dari 41 responden yang memiliki sikap positif terdapat 26 responden $(63,4 \%)$ yang siap dalam menghadapi menopause. Setelah dilakukan uji statistik chi-square didapat nilai $p$ value $=0,006(\mathrm{p}<$ 0,05 ) yang artinya ada hubungan sikap dengan kesiapan ibu menghadapi menopause di Wilayah Kerja Puskesmas Guguk Panjang Tahun 2019 (11).

Sikap adalah ekspresi perasaan (inner feeling), yang mencerminkan apakah sesorang senang atau tidak senang, suka atau tidak suka, dan setuju atau tidak terhadap sesuatu objek.. Sikap sebagai predisposisi yang dipelajari (learned predisposition) untuk berespon terhadap suatu objek atau kelas objek dalam suatu menyenangkan atau tidak menyenangkan secara konsisten. Sikap dapat disimpulkan berupa kecenderungan individu untuk memahami, merasakan, bereaksi dan berprilaku terhadap suatu objek yang merupakan hasil dari interaksi komponen kognitif, afektif dan konatif (12).

Secara kualitatif diketahui bahwa sikap informan 1, informan 2 dan informan 3 berpendapat bahwa menopause pada setiap perempuan itu adalah hal yang wajar dan akan dilalui oleh setiap wanita, informan 1, informan 2 dan informan 3 juga mengatakan bahwa gejala menopause tidak mengganggu aktivitas sehari - hari, informan 1, informan 2 dan informan 3 juga mengatakan bahwa akan menerima masa menopause kelak, dan informan 1, informan 2, informan 3 juga mengatakan bahwa akan menerima perubahan yang terjadi pada fisik dan psikologis pada masa menopause karena perubahan yang terjadi adalah perubahan yang wajar pada setiap wanita.

Menurut temuan peneliti bahwa ibu premenopause yang memiliki sikap positif cenderung lebih siap dalam menghadapi masa menopause yang akan datang. Sikap ibu premenopause dalam menghadapi masa menopause juga merupakan penilaian wanita terhadap kesiapan menghadapi menopause. Mengatasi gejala-gejala pada saat memasuki menopause, wanita perlu mengenali gejala - gejalanya dan mengatasinya dengan bijak serta penting bagi wanita untuk sering berfikir positif bahwa kondisi tersebut merupakan sesuatu yang sifatnya alami. Tentunya sikap positif ini bisa muncul jika diimbangi oleh informasi atau pengetahuan yang cukup serta kesiapan fisik, mental dan spiritual yang dilakukan pada masa sebelumnya sehingga ketika masa ini datang keluhan - keluhan ketidaknyamanan maupun yang menyakitkan dapat dikurangi bahkan ditiadakan.

\section{Pengaruh Tingkat Stress Terhadap Kesiapan Ibu Premenopause Menghadapi Menopause di Asrama Khatulistiwa Kota Pontianak}

Berdasarkan hasil tabulasi silang menunjukkan bahwa dari 19 responden ibu premenopause dengan tidak stress didapatkan $16(33,3 \%)$ yang siap menghadapi masa 
menopause, dari 24 responden ibu premenopause dengan stress ringan didapatkan 13 $(27,1 \%)$ yang tidak siap menghadapi masa menopause dan dari 5 responden ibu premenopause dengan stress sedang didapatkan $4(8,3 \%)$ yang tidak siap menghadapi masa menopause. Dari hasil uji statistik, chi-square diperoleh nilai kemaknaan $\mathrm{p}=0,007(<0,05)$, maka dapat di simpulkan bahwa ada pengaruh tingkat stress terhadap kesiapan ibu premenopause menghadapi masa menopause.

Hasil penelitian ini sejalan dengan penelitian oleh Mayang Wulan yang menunjukkan bahwa dari 20 responden dengan tingkat stres normal yang memiliki kesiapan rendah sebanyak 7 responden $(12,1 \%)$ dan yang memiliki kesiapan yang tinggi dalam menghadapi menopause sebanyak 13 responden $(22,4 \%)$. Dari 15 responden yang memiliki tingkat stres ringan yang memiliki kesiapan yang rendah sebanyak 7 responden $(12,1 \%)$ dan yang memiliki kesiapan yang tinggi dalam menghadapi menopause sebanyak 8 responden $(13,8 \%)$. Ibu yang memiliki tingkat stres sedang sebanyak 9 responden dan seluruhnya memiliki kesiapan yang rendah dalam menghadapi menopause. Ibu yang memiliki stres berat sebanyak 12 responden diantaranya yang memiliki kesiapan yang memiliki kesiapan yang rendah sebanyak 2 responden $(3,4 \%)$ dan yang memiliki kesiapan tinggi dalam menghadapi menopause sebanyak 10 responden $(17,2 \%)$. Sedangkan ibu yang memiliki tingkat stres sangat berat sebanyak 2 responden dan seluruhnya memiliki kesiapan yang rendah dalam menghadapi menopause. Dari hasil uji statistik diperoleh nilai kemaknaan $p=0,001(<0,05)$, maka dapat di simpulkan bahwa ada hubungan tingkat stress dengan kesiapan ibu menghadapi masa menopause pada ibu pramenopause di Kelurahan Gundaling (13).

Stress adalah suatu kondisi pada individu yang tidak menyenangkan dimana dari hal tersebut dapat menyebabkan terjadinya tekanan fisik maupun psikologis pada individu (14).Stress adalah respon tubuh yang sifatnya non spesifik terhadap setiap tuntutan beban atasnya. Misalnya bagaimana respon tubuh seseorang manakala yang bersangkutan mengalami beban pekerjaan yang berlebihan. Bila ia sanggup mengatasinya artinya tidak ada gangguan pada fungsi organ tubuh, maka dikatakan yang bersangkutan tidak mengalami stress. Stress dan kecemasan juga dapat disebabkan karena keadaan biologis seseorang. Keadaan biologis ini dapat mendahului konflik psikologis namun bisa juga sebagai akibat dari suatu konflik psikologis.

Secara kualitatif diketahui bahwa informan 1 mengatakan dalam keadaan baik dan tidak sulit untuk beristirahat, merasa bertambahnya umur semakin mudah tersinggung, emosi dan cepat tidak sabar, pada informan 2 mengatakan dalam keadaan baik dan tidak sulit untuk beristirahat kecuali ada kegiatan tambahan tertentu, merasa lebih sensitif pada perasaan, mudah marah dan perasaan mudah berubah, sedangkan pada informan 3 mengatakan dalam keadaan baik dan sulit untuk beristirahat karena pekerjaan, mencoba untuk selalu bersabar dan mengontrol emosi.

Menurut temuan peneliti bahwa ibu premenopause dengan kondisi tidak stress lebih siap menghadapi masa menopause dibandingkan dengan ibu yang mengalami kondisi stress ringan ataupun stress sedang. Pada masa transisi dari periode reproduktif ke periode nonreproduktif menuntut penyesuaian diri terhadap perubahan fisik dan peranan. Cara wanita dalam menghadapi transisi tergantung pada kestabilan emosi, pengalaman masa lalu dalam menghadapi perubahan, serta pengharapan di masa mendatang. Pandangan seseorang mengenai menopause sangat memengaruhi perubahan psikologis pada masa menopause mendatang. Pandangan ini dipengaruhi oleh faktor yang berasal dari dalam diri individu serta faktor yang berasal dari lingkungan sosial. Persepsi tentang menopause dengan tingkat stress pada wanita yang akan menghadapi masa menopause yang menyebutkan semakin positif persepsi seorang wanita tentang menopause maka akan semakin rendah tingkat stressnya. 


\section{Pengaruh Dukungan Keluarga Terhadap Kesiapan Ibu Premenopause Menghadapi Menopause di Asrama Khatulistiwa Kota Pontianak}

Berdasarkan hasiltabulasi silang menunjukkan bahwa dari 33 responden ibu premenopause dengan dukungan keluarga yang mendukung didapatkan $24(50 \%)$ yang siap menghadapi masa menopause dan dari 15 responden ibu premenopause dengan dukungan keluarga yang tidak mendukung didapatkan $11(22,9 \%)$ yang tidak siap menghadapi masa menopause. Dari hasil uji statistik chi-square diperoleh nilai kemaknaan $\mathrm{p}=0,004(<0,05)$, maka dapat di simpulkan bahwa ada pengaruh dukungan keluarga terhadap kesiapan ibu premenopause menghadapi masa menopause.

Hasil penelitian ini sejalan dengan penelitian Mery Maki, perhitungan analisis chisquare pada hubungan dukungan keluarga dengan kesiapan menghadapi menopause diperoleh nilai $p$ value $=0,001$, maka dapat disimpulkan ada pengaruh dukungan keluarga terhadap kesiapan wanita menghadapi menopause di Desa Sumarayar (15).

Dukungan keluarga merupakan bentuk dari prilaku keluarga yang diharapkan oleh orang lain sesuai kedudukannya dalam suatu sistem. Keluarga diharapkan dapat mengambil bagian untuk berprilaku sesuai dengan fungsinya masing - masing. Dukungan keluarga merupakan bentuk dari bantuan keluarga kepada wanita yang akan memasuki masa menopause (16).

Secara kualitatif diketahui bahwa informan 1 mengatakan keluarga memberikan rasa aman dan nyaman, namun tidak pernah untuk menyarankan membaca informasi tentang menopause dari sumber media manapun, pada informan 2 mengatakan keluarga memberikan rasa aman dan nyaman, ada dukungan dari anak perempuannya untuk sering mencari informasi tentang menopause dari sumber internet, sedangkan informan 3 mengatakan keluarga memberikan rasa aman dan nyaman, memberikan saran untuk mebaca artikel kesehatan lewat media apapun.

Menurut temuan peneliti bahwa ibu premenopause yang mendapat dukungan dari keluarga lebih siap menghadapi masa menopause dibandingkan dengan ibu premenopause yang tidak mendapat dukungan dari keluarga. Perempuan dalam menghadapi masa menopause membutuhkan dukungan dari orang terdekat seperti dukungan dari seorang suami biasanya berupa sikap, dorongan, tindakan dan penerimaan. Dukungan suami adalah hal yang penting karena akan menurunkan kecemasan istri dalam menghadapi masa menopause. Permasalahan yang sering dikhawatirkan oleh istri adalah masalah mengenai seksualitas, akan tetapi dampak buruknya dapat dikurangi dengan adanya dukungan dari suami.

\section{Pengaruh Aktivitas Fisik Terhadap Kesiapan Ibu Premenopause Menghadapi Menopause di Asrama Khatulistiwa Kota Pontianak}

Berdasarkan hasil tabulasi silang menunjukkan bahwa dari 8 responden ibu premenopause dengan aktivitas fisik rendah didapatkan $8(16,7 \%)$ yang siap menghadapi masa menopause, dari 34 responden ibu premenopause dengan aktivitas fisik sedang didapatkan $19(39,6 \%)$ yang siap menghadapi masa menopause dan dari 6 responden ibu premenopause dengan aktivitas fisik tinggi didapatkan $5(10,5 \%)$ yang tidak siap menghadapi masa menopause. Dari hasil uji statistik, chi-square diperoleh nilai kemaknaan $\mathrm{p}=0,006(<0,05)$, maka dapat di simpulkan bahwa ada pengaruh aktivitas fisik terhadap kesiapan ibu premenopause menghadapi masa menopause.

Aktivitas fisik adalah setiap gerakan tubuh yang membutuhkan energi untuk mengerjakannya, seperti berjalan, menari, mengasuh cucu, dan lain sebagainya. Sedangkan olahraga merupakan kegiatan fisik yang terencana dan terstruktur serta melibatkan gerakan tubuh berulang-ulang untuk meningkatkan kebugaran jasmani (17). 
Secara kualitatif diketahui bahwa informan 1 dan informan 2 melakukan aktivitas pekerjaan rumah sehari-hari pada umumnya seperti menyapu rumah, mengepel, mencuci piring, mencuci pakaian, memasak, menyetrika pakaian serta melakukan olahraga volly di sore hari, sedangkan pada informan 3 melakukan aktivitas pekerjaan rumah sehari-hari pada umumnya ditambah dengan kegiatan pekerjaan sebagai seorang guru.

Menurut temuan peneliti bahwa ibu premenopause dengan aktivitas sedang lebih siap menghadapi masa menopause dibandingkan dengan ibu premenopause dengan aktivitas yang rendah.. Aktivitas fisik yang dilakukan secara teratur oleh ibu premenopause dapat mengurangi berbagai keluhan akibat gejala menopause, memperbaiki kesehatan secara menyeluruh, menetralkan depresi, meningkatkan kapasitas untuk bekerja dan mengarah pada kehidupan yang lebih aktif, serta memberikan rasa kepercayaan diri. Aktivitas fisik teratur lebih dari 60 menit setiap hari akan menurunkan gejala menopause, meningkatkan kualitas hidup pada domain psikologi dan dukungan sosial serta meningkatkan kesiapan menghadapi masa menopause. Aktivitas fisik, seperti berolahraga dapat menyehatkan jantung dan tulang, menyegarkan tubuh dan dapat memperbaiki suasana hati sehingga dapat meningkatkan kualitas hidup menopause dan siap menghadapi masa menopause yang akan datang.

\section{Kesimpulan Dan Saran}

Berdasarkan hasil penelitian, maka dapat disimpulkan bahwa ada pengaruh antara tingkat pendidikan, status pekerjaan, pengetahuan, sikap, tingkat stress, dukungan keluarga dan aktivitas fisik terhadap kesiapan ibu premenopause menghadapi masa menopause di Komplek Asrama Khatulistiwa Kota Pontianak Tahun 2021. Diharapkan penelitian ini dapat menjadi informasi dalam memberikan pemahaman kepada ibu premenopause dalam mempersiapkan diri untuk menghadapi perubahan - perubahan yang akan terjadi pada masa menopause, tentang bagaimana cara menghadapi menopause, bagaimana mengurangi keluhan - keluhan yang terjadi dan dengan pemahaman yang baik diharapkan dapat mengurangi beban fisik dan mental yang akan memengaruhi kesiapan wanita dalam menjalani masa tersebut serta disarankan dapat menambah pengetahuan tentang kesehatan reproduksi khususnya tentang masa menopause melalui media informasi lainnya.

\section{Daftar Pustaka}

Barat BPSPK. http://kalbar.bps.go.id. [Online].; 2020 [cited 2021 May 16.

Dewinny S, Emielda A. Psikologi Kebidanan : Memahami Psikis Wanita Sepanjang Daur Hidup dalam Pelayanan Kebidanan Yogyakarta: Pustaka Baru Press; 2019.

Dyah B. Budaya, Negara, dan Status Sosial Ekonomi Perempuan, Sebuah Refleksi Konsep Ibu Rumah Tangga. Dinamika Kependudukan dan Kebijakan Yogyakarta: Pusat Studi Kependudukan dan Kebijakan Universitas Gajah Mada; 2006.

Franchise C. Langkah Pertama Melalui Menopause Jakarta: Libri; 2017.

Harmoko. Asuhan Keperawatan Keluarga Semarang: Pustaka Pelajar; 2012

Indonesia PK. http://www.depkes.go.id. [Online].; 2019 [cited 2021 May 15.

Khomarun, K., Nugroho, M. A., \& Wahyuni, E. S. (2014). Pengaruh aktivitas fisik jalan pagi terhadap penurunan tekanan darah pada lansia dengan hipertensi stadium I di Posyandu Lansia Desa Makamhaji. Interest: Jurnal Ilmu Kesehatan, 3(2). 
Maki M. Faktor - Faktor Yang Mempengaruhi Kesiapan Wanita Menghadapi Menopause Di Desa Sumarayar Kecamatan Langowan Timur. Skripsi. Manado: Universitas Khatolik De La Salle, Program Studi Ilmu Keperawatan; 2016.

Manurung. Terapi Reminiscence Jakarta: CV. Trans Info Media; 2016.

Notoatmodjo S.Pendidikan \&Perilaku Kesehatan Jakarta: Rineka Cipta; 2003.

Purwatyastuti. Premenopause, 2008. Available from: luluvikar.wordpress.com

Sari, N. W., \& Yuniliza, Y. (2020). Faktor-Faktor Yang Berhubungan Dengan Kesiapan Ibu Menghadapi Menopause Di Wilayah Kerja Puskesmas Guguk Panjang. Menara Ilmu, 14(1).

Sasrawita, S. (2017). Hubungan pengetahuan, sikap tentang menopause dengan kesiapan menghadapi menopause di puskesmas pekanbaru. Jurnal Endurance: Kajian Ilmiah Problema Kesehatan, 2(2), 117-123.

Tirtahardja D. Pengantar Pendidikan Jakarta: Rineka Cipta; 2005

Wahyuni, S., Yusrizal, Y., \& Wardiati, W. (2020). Faktor-Faktor Yang Mempengaruhi Kesiapan Wanita Usia 40-50 Tahun Dalam Menghadapi Menopause Di Kecamatan Langsa Timur Kota Langsa. Jukema (Jurnal Kesehatan Masyarakat Aceh), 6(1), 412.

Wulan, M. (2020). Faktor Yang Berhubungan Dengan Kesiapan Menghadapi Menopause Pada Ibu Pramenopause Associated Factors In Facing Menopouse Readiness Of Premenopouse. Jurnal Kebidanan, 9(2), 70.

Yunus, S. (2018). Analisis Faktor Yang Mempengaruhi Kesiapan Ibu Premenopause Menghadapi Menopause Di Puskesmas Kassi-Kassi Makassartahun 2016. Jurnal Ilmiah Kesehatan Diagnosis, 12(4), 394-399. 